Tropical Journal of Pharmaceutical Research January 2021; 20 (1): 113-119

ISSN: $1596-5996$ (print); 1596-9827 (electronic)

(C) Pharmacotherapy Group, Faculty of Pharmacy, University of Benin, Benin City, 300001 Nigeria.

\title{
Protective effect of leaf extract of Ficus carica L. against carbon tetrachloride-induced hepatic toxicity in mice and HepG2 cell line
}

\author{
Syeda Hira ${ }^{1 *}$, Muhammad Gulfraz ${ }^{1}$, SM Saqlan Naqvi ${ }^{1}$, Rehmat Ullah Qureshi², $^{2}$ \\ Hina Gul ${ }^{1}$ \\ ${ }^{1}$ Department of Biochemistry, ${ }^{2}$ Department of Botany, Pir Mehr Ali Shah, Arid Agriculture University, Rawalpindi 46000, \\ Pakistan \\ *For correspondence: Email: hiranaqvi22@yahoo.com; Tel: +92-3365406913
}

Sent for review: 3 July 2020

Revised accepted: 17 December 2020

\begin{abstract}
Purpose: To determine the in vivo and in vitro hepatoprotective effects of Ficus carica.

Methods: The methanol leaf extract of Ficus carica $L$ was further fractionated into $n$-hexane, ethyl acetate and aqueous fractions. For in vivo study, male albino mice were divided into twelve groups. Hepatotoxicity was induced in the mice using carbon tetrachloride $\left(\mathrm{CCl}_{4}\right)$. The extract of $\mathrm{F}$. carica and its fractions were administered at doses of 200 and $400 \mathrm{mg} / \mathrm{kg}$. Silymarin was used as standard hepatoprotective drug. The protective effects of the extract and fractions were determined via assay of biochemical parameters and antioxidant enzymes in the liver. The histopathology of the liver was also studied. Moreover, the in vitro hepatoprotective effect of the extract and fractions against $\mathrm{CCl}_{4}$-induced damage was determined in HepG2 cell line.

Results: There were significant increases in the serum levels of liver biomarkers in $\mathrm{CCl}_{4}$-treated group, whereas treatments with plant extract and fractions significantly reduced the levels of these parameters $(p<0.05)$. In addition, results from histopathology revealed evidence of protective effect of Ficus carica through reversal of $\mathrm{CCl}_{4}$-induced decreases in the activities of liver antioxidant enzymes.

Conclusion: These results indicate that methanol leaf extract of Ficus carica $L$. and its fractions exert significant and dose-dependent hepatoprotective effects in vivo and in vitro.
\end{abstract}

Keywords: Ficus carica, Hepatoprotection, Carbon tetrachloride, Liver biomarkers

\begin{abstract}
This is an Open Access article that uses a fund-ing model which does not charge readers or their institutions for access and distributed under the terms of the Creative Commons Attribution License (http://creativecommons.org/licenses/by/4.0) and the Budapest Open Access Initiative (http://www.budapestopenaccessinitiative.org/read), which permit unrestricted use, distribution, and reproduction in any medium, provided the original work is properly credited.

Tropical Journal of Pharmaceutical Research is indexed by Science Citation Index (SciSearch), Scopus, International Pharmaceutical Abstract, Chemical Abstracts, Embase, Index Copernicus, EBSCO, African Index Medicus, JournalSeek, Journal Citation Reports/Science Edition, Directory of Open Access Journals (DOAJ), African Journal Online, Bioline International, Open-J-Gate and Pharmacy Abstracts
\end{abstract}

\section{INTRODUCTION}

Liver diseases are serious health problems. Indeed, approximately $2 \%$ of total deaths are due to liver disorders. The liver is a vital organ which performs many functions such as storage, metabolism, secretion and detoxification. It maintains physiological homeostasis. The liver is the largest organ in humans, and it is susceptible to chemical-induced toxicity. Hepatic damage is initiated by over-production of reactive oxygen species (ROS) [1]. Reactive oxygen species (ROS) interact with, and modify biomolecules such as proteins, lipids and DNA, resulting in various degenerative diseases. The liver 
contains a natural defense system of antioxidant enzymes comprising peroxidases, superoxide dismutase (SOD), catalase (CAT) and reductases, all of which combat ROS so as to overcome oxidative stress [2]. Carbon tetrachloride $\left(\mathrm{CCl}_{4}\right)$ is used to induce hepatoxicity in animal models. In the liver, cytochrome p450 converts $\mathrm{CCl}_{4}$ to trichloromethyl free radical $\left(\cdot \mathrm{CCl}_{3}\right)$ which subsequently binds to membrane proteins and lipids, resulting in lipid peroxidation and loss of hepatocyte membrane integrity [3].

Liver diseases are mostly not completely curable with allopathic medicines, although this issue has remained controversial. Thus, current research is focused on hepatoprotective compounds obtained from plants due to the fact that these compounds have no adverse side effects. For thousands of years, several populations have relied on medicinal plants rather than synthetic drugs for their primary health care needs [4].

Ficus carica is a deciduous tree belonging to the family Moraeceae. It grows well in tropical and subtropical regions. The plant has been used for centuries to cure different diseases. Traditionally the leaves and fruit latex of Ficus carica are used for treating jaundice, gout, anemia and antiinflammatory. Studies have revealed the presence of various bioactive compounds such as phenols, flavonoids, triterpenoids, cardiac glycosides and alkaloids in the leaves, fruit, stem and latex of Ficus carica plant [5].

The purpose of the present study was to determine the hepatoprotective effects of methanol leaf extract of Ficus carica and its derived fractions against $\mathrm{CCl}_{4}$-induced toxicity. Furthermore, the in vitro protective effects of the extract and its fractions were determined in HepG2 cell line.

\section{EXPERIMENTAL}

\section{Plant material}

Ficus carica leaves were collected from Islamabad, Pakistan in the month of July 2016. Authentication of sample was done by $\mathrm{Dr}$ Rehmatullah Qureshi, Associate Professor in Botany Department, Pir Mehr Ali Shah Arid Agriculture University, Rawalpindi, Pakistan. A voucher specimen of the plant was deposited in the herbarium of the University (voucher no Bot 2459).

\section{Extraction and fractionation of plant material}

After cleaning and shade-drying, the leaves were ground into fine powder using an electrical grinder. The preparation of the extract was done using a simple maceration process. A portion of the powdered leaves was soaked in methanol for $72 \mathrm{~h}$ at room temperature, after which the mixture was filtered through Whatmann no 1 filter paper. Then, the solvent was evaporated under reduced pressure in a rotatory evaporator (Heidolph, Germany). The methanolic extract was mixed with water and subjected to partitioning in a separating funnel using solvents of increasing polarity (n-hexane, ethyl acetate and water). Following solvent evaporation from the extract and its fractions, the dried samples were kept $4{ }^{\circ} \mathrm{C}$ prior to use.

\section{Animals and experimental design}

Male albino mice were obtained from National Institute of Health, Islamabad. The animals were housed in stainless steel cages, with free access to water and laboratory diet. The study received approval from the ethical committee of PMASAAUR (approval no. PMAS_AAUR/BCH/326), and the experimental procedure used for the animals were carried out in line according to National Institutes of Health guidelines. The mice were divided into 12 groups, with 5 mice in each group. The study was performed for two weeks. Group I (normal healthy group) received normal saline only. Group II (vehicle control mice) were treated with olive oil only. Group III (toxic control mice) received $\mathrm{CCl}_{4}$ intraperitonially at a dose of $0.2 \mathrm{~mL} / \mathrm{kg}$. Mice in group IV were treated with the standard drug silymarin and $\mathrm{CCl}_{4}$ twice a week. Groups V and VI mice were administered methanol extract at doses of 200 and $400 \mathrm{mg} / \mathrm{kg}$, respectively, post-orally. Mice in groups VII and VIII were served with $n$-hexane fraction at doses of 200 and $400 \mathrm{mg} / \mathrm{kg}$, respectively, in addition to $\mathrm{CCl}_{4}$, twice a week. Group IX and group X were treated with ethyl acetate fraction at doses of 200 and $400 \mathrm{mg} / \mathrm{kg}$, respectively, while mice in group $\mathrm{XI}$ and group XII received the aqueous fraction at doses of 200 and $400 \mathrm{mg} / \mathrm{kg}$, respectively.

\section{Biochemical analysis}

Blood samples were collected from all animals using direct cardiac puncture. Serum samples were obtained by centrifugation of the blood samples at $3000 \mathrm{rpm}$ for $10 \mathrm{~min}$. The method described by Qureshi et al [6] was used for estimation of liver biomarkers i.e. alanine transaminase (ALT), aspartate aminotransferase (AST), alkaline phosphatase (ALP) and total bilirubin. The assays were done using commercially available kits in line with the kit manufacturers' protocols. Serum total protein was determined with Lowry's method [7].

Trop J Pharm Res, January 2021; 20(1): 114 


\section{Determination of activities of liver antioxidant enzymes}

Liver tissue homogenate was prepared by grinding $100 \mathrm{mg}$ of fresh liver tissue with $1 \mathrm{~mL}$ of potassium phosphate buffer (100 mM, pH 7.4). The homogenate was centrifuged at $12000 \mathrm{~g}$ for 30 min at $4^{\circ} \mathrm{C}$, and the supernatant was used for assay the activities of antioxidant enzymes [8]. Catalase (CAT) activity was determined using method of Chance [9], while the activity of SOD was determined using the method of Kakkar [10]. Glutathione peroxidase (GPx) activity was assayed using the method of Lawrence and Burk [11].

\section{Histopathological studies}

Liver samples dissected out from mice of all groups were fixed in $10 \%$ formalin. The fixed tissues were processed by dehydration in increasing concentrations of ethanol, followed by embedding in paraffin. Then, 5- $\mu \mathrm{m}$ tissue slices were sectioned, put on slides and stained with haematoxylin and eosin $(H \& E)$. The tissue slides were observed under a light microscope (Am Scope, USA) and photographed.

\section{In vitro hepatoprotective effect of extract and fractions against $\mathrm{CCl}_{4}$-induced damage}

In vitro hepatoprotective screening was based on protection of HepG2 cells [12]. Toxicity was induced using $\mathrm{CCl}_{4}$, and the in vitro hepatoprotective effect was determined using MTT assay based on mitochondrial viability. The HepG2 cell line was obtained from Institute of Biomedical and Genetic Engineering, KRL Hospital Islamabad. The cells were cultured in 96-well plates at density of $1.0 \times 10^{5}$ cells/well in Dulbecco's modified Eagle's medium (DMEM) supplemented with $10 \%$ fetal bovine serum (FBS) overnight at $37{ }^{\circ} \mathrm{C}$ in a humidified atmosphere of $5 \% \mathrm{CO}_{2}$. A partial monolayer was formed after $24 \mathrm{~h}$. The culture medium (supernatant) was removed, and the monolayer was washed. Then, the cells were exposed to $\mathrm{CCl}_{4}$ and different concentrations of the plant extract fractions $(0.1,1$ and $10 \mu \mathrm{g} / \mathrm{mL})$. After 24 $\mathrm{h}$, the medium was discarded and each well was rinsed with phosphate buffered saline (PBS). Then, $0.05 \%$ 3-(4, 5-dimethylthiazol-2-yl)-2,5diphenyltetrazolium bromide (MTT) was added to each well and incubated for $2 \mathrm{~h}$. Thereafter, the MTT was aspirated off, and the resultant blue formazan crystals were dissolved in DMSO. The absorbance of the formazan solution in each well was measured at $540 \mathrm{~nm}$ using a microplate reader (BioRad).

\section{Statistical analysis}

Values are expressed as mean \pm standard deviation (SD). The effects of the different treatments were compared using one-way analysis of variance (ANOVA), followed by Dunnett's post-test. Computer software GraphPad prism 5.0 was used. Statistical significance was assumed at $p<0.05$.

\section{RESULTS}

\section{Effect of $\boldsymbol{F}$. carica on liver biomarkers}

As shown in Table 1, treatment with $\mathrm{CCl}_{4}$ led to significant increases in the serum levels of liver biomarker enzymes i.e. ALT, AST and ALP, as well as total bilirubin, while the level of serum total protein was reduced, relative to the normal control mice $(p<0.05)$. However, interestingly, treatment with plant extract and fractions reversed the increases in the levels of these enzymes. The ethyl acetate fraction produced the most significant effect $(p<0.05)$. Treatment with ethyl acetate fraction at a higher dose (400 $\mathrm{mg} / \mathrm{kg}$ ) led to significant decreases $(p<0.05)$ in the serum levels of liver marker enzymes to levels almost similar to those in the silymarintreated group. The least hepatoprotective potential was exhibited by the n-hexane fraction.

\section{Effect of $F$. carica on liver enzymes}

As shown in Table $2, \mathrm{CCl}_{4}$ reduced the activities of the liver enzymes CAT, SOD and GPx, when compared with normal control group. However, treatment with ethyl acetate fraction at doses of 200 and $400 \mathrm{mg} / \mathrm{kg}$ resulted in enhancement of the activities of these enzymes. Moreover, the methanol extract and aqueous fraction reduced the activities of the liver enzymes. The effects of the extract and fractions were dose-dependent. Maximum potential was produced at the higher dose of $400 \mathrm{mg} / \mathrm{kg}$. The $\mathrm{n}$-hexane fraction produced low oxidative potential. In addition, the Ficus carica extract increased serum protein levels, thereby reversing the $\mathrm{CCl}_{4}$-induced reduction in protein levels.

\section{Histopathological features}

Liver sections from mice in the healthy group had normal hepatocyte structure, with normal sinusoidal spaces and central vein (Figure 1). However, $\mathrm{CCl}_{4}$ administration resulted in complete loss of liver architecture, necrosis, dilation of central vein and congested sinusoidal spaces. 
Table 1: Effect of Ficus carica L. extract and its fractions on serum biochemical parameters

\begin{tabular}{|c|c|c|c|c|}
\hline Group & ALT (U/L) & AST (U/L) & ALP (U/L) & Total bilirubin (g/dL) \\
\hline Normal control & $34.5 \pm 3.46$ & $32.4 \pm 2.10$ & $63.2 \pm 3.62$ & $0.20 \pm 0.27$ \\
\hline Vehicle control & $35.2 \pm 1.53$ & $35.2 \pm 2.81$ & $65.6 \pm 2.40$ & $0.29 \pm 1.81$ \\
\hline Toxic control & $198 \pm 3.19^{\star *}$ & $136.7 \pm 2.94^{\star *}$ & $329 \pm 3.18^{* *}$ & $2.86 \pm 0.45^{* *}$ \\
\hline Silymarin & $40.5 \pm 2.14^{\# \#}$ & $48.6 \pm 3.73^{\# \#}$ & $79.2 \pm 2.36$ & $0.30 \pm 0.97$ \\
\hline ME 200 mg/kg & $85.4 \pm 2.96$ & $90.2 \pm 3.56$ & $104 \pm 2.45$ & $0.56 \pm 2.90$ \\
\hline 400 mg/kg & $64.3 \pm 3.28$ & $61 \pm 2.29$ & $84 \pm 3.19$ & $0.34 \pm 1.21^{\# \#}$ \\
\hline NHF 200 mg/kg & $133.4 \pm 3.91$ & $95.9 \pm 2.46$ & $176.4 \pm 2.57$ & $0.48 \pm 0.11$ \\
\hline 400 mg/kg & $125.6 \pm 3.20$ & $84.6 \pm 3.04$ & $184.9 \pm 2.74$ & $0.52 \pm 0.08$ \\
\hline EAF $200 \mathrm{mg} / \mathrm{kg}$ & $50.2 \pm 3.15$ & $59.0 \pm 5.49$ & $83.6 \pm 1.86$ & $0.44 \pm 0.26$ \\
\hline $400 \mathrm{mg} / \mathrm{kg}$ & $44.9 \pm 1.81^{\# \#}$ & $51 \pm 3.53^{\# \#}$ & $76.2 \pm 2.48^{\# \#}$ & $0.76 \pm 0.11$ \\
\hline AQF $200 \mathrm{mg} / \mathrm{kg}$ & $85 \pm 3.33$ & $74.4 \pm 2.61^{\# \#}$ & $126.6 \pm 1.99$ & $0.80 \pm 0.71$ \\
\hline $400 \mathrm{mg} / \mathrm{kg}$ & $65.6 \pm 3.78$ & $66.2 \pm 2.86$ & $173.2 \pm 1.92$ & $0.80 \pm 0.10$ \\
\hline
\end{tabular}

Table 2: Effect of Ficus carica L. extract and its fractions on liver enzymes and total protein

\begin{tabular}{lcccc}
\hline Group & $\begin{array}{c}\text { CAT (U/mg } \\
\text { protein) }\end{array}$ & $\begin{array}{c}\text { SOD (U/mg } \\
\text { protein) }\end{array}$ & GPx (mol/min/mg protein) & $\begin{array}{c}\text { Total protein in } \\
\text { serum (g/dL) }\end{array}$ \\
\hline Normal control & $7.64 \pm 2.18$ & $11.8 \pm 2.56$ & $39.8 \pm 2.94$ & $5.90 \pm 2.13$ \\
Vehicle control & $5.90 \pm 3.24$ & $9.94 \pm 2.49$ & $29.3 \pm 3.36$ & $5.56 \pm 1.59$ \\
Toxic control & $2.20 \pm 2.96^{*}$ & $5.40 \pm 3.17^{*}$ & $24.2 \pm 3.31^{*}$ & $3.38 \pm 2.45^{*}$ \\
Silymarin & $6.20 \pm 2.16^{\#}$ & $9.10 \pm 2.16^{\#}$ & $34.6 \pm 1.78^{\#}$ & $5.16 \pm 1.69^{\#}$ \\
ME $200 \mathrm{mg} / \mathrm{kg}$ & $4.60 \pm 2.97$ & $8.14 \pm 2.90$ & $32.9 \pm 2.17$ & $5.18 \pm 2.38$ \\
$400 \mathrm{mg} / \mathrm{kg}$ & $4.91 \pm 1.16$ & $8.66 \pm 1.67$ & $33.5 \pm 2.96$ & $5.51 \pm 1.96$ \\
NHF $200 \mathrm{mg} / \mathrm{kg}$ & $3.78 \pm 1.18$ & $7.72 \pm 2.81$ & $25.4 \pm 1.89^{*}$ & $4.00 \pm 1.90$ \\
$400 \mathrm{mg} / \mathrm{kg}$ & $3.38 \pm 3.67$ & $7.82 \pm 3.42$ & $30.4 \pm 2.67$ & $4.34 \pm 1.41$ \\
EAF $200 \mathrm{mg} / \mathrm{kg}$ & $5.26 \pm 2.78$ & $8.69 \pm 2.48$ & $37 \pm 1.18$ & $5.18 \pm 2.76^{\#}$ \\
$400 \mathrm{mg} / \mathrm{kg}$ & $5.72 \pm 2.3^{\#}$ & $9.00 \pm 3.78^{\#}$ & $35.5 \pm 1.54^{\#}$ & $5.27 \pm 2.90^{\#}$ \\
AQF $200 \mathrm{mg} / \mathrm{kg}$ & $4.30 \pm 1.98$ & $8.00 \pm 2.45$ & $27.4 \pm 2.28$ & $4.44 \pm 1.56$ \\
$400 \mathrm{mg} / \mathrm{kg}$ & $4.80 \pm 3.78$ & $8.20 \pm 1.89$ & $32.5 \pm 2.76$ & $4.58 \pm 2.55$ \\
\hline
\end{tabular}

Values are expressed as mean \pm S.D. ${ }^{*} P<0.05$ ), compared to normal group; ${ }^{\#} p<0.05$, compared to $\mathrm{CCl}_{4}$ toxic control. $(\mathrm{CAT}=$ catalase, $\mathrm{SOD}=$ superoxide dismutase, $\mathrm{GPx}=$ glutathione peroxidase $)$
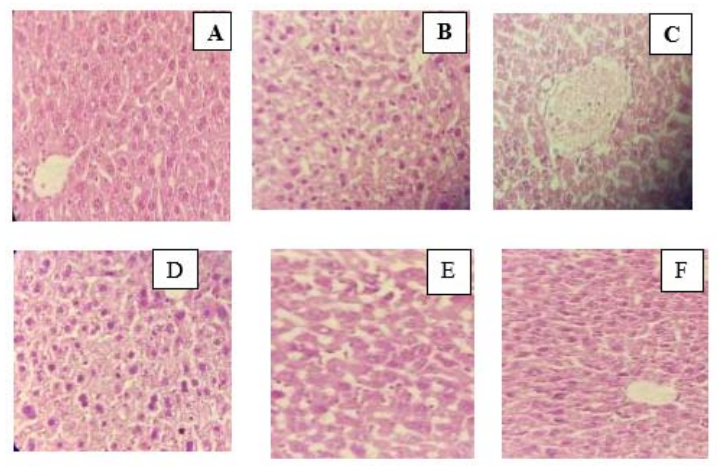

Figure 1: Histopathology of liver sections of mice. A: Liver section from normal control, B: liver section from mice treated with olive oil (olive oil control), C: liver section from mice given $\mathrm{CCl}_{4}$ only, D: liver section from mice treated with silymarin, E: liver section from mice that received methanolic extract $(200 \mathrm{mg} / \mathrm{kg})+$ $\mathrm{CCl}_{4}$, and $\mathbf{F}$ : liver section from mice given methanolic extract $(400 \mathrm{mg} / \mathrm{kg})+\mathrm{CCl}_{4}$.

These $\mathrm{CCl}_{4}$-induced lesions were reversed by treatment with methanol leaf extract of Ficus carica and its fractions, as shown in Figure 2. At a dose of $400 \mathrm{mg} / \mathrm{kg}$, the protective effect of the ethyl acetate fraction on hepatocytes was similar to that produced by the hepatoprotective agent silymarin.
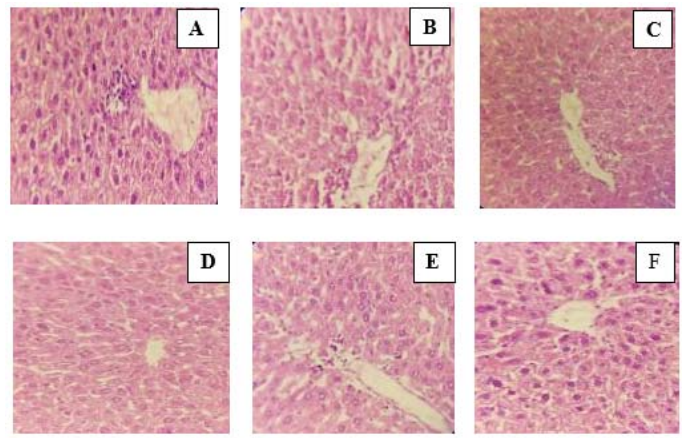

Figure 2: Histopathology of liver sections of mice. A: Liver section from mice given $n$-hexane fraction (200 $\mathrm{mg} / \mathrm{kg})+\mathrm{CCl}_{4}$, B: liver section from mice given $\mathrm{n}$ hexane fraction $(400 \mathrm{mg} / \mathrm{kg})+\mathrm{CCl}_{4}$, C: liver section from mice given ethyl acetate fraction $(200 \mathrm{mg} / \mathrm{kg})+$ $\mathrm{CCl}_{4}$, D: liver section from mice given ethyl acetate fraction $(400 \mathrm{mg} / \mathrm{kg})$, E: liver section from mice given aqueous fraction $(200 \mathrm{mg} / \mathrm{kg})+\mathrm{CCl}_{4}$, and $\mathrm{F}$ : liver section from mice that received aqueous fraction (400 $\mathrm{mg} / \mathrm{kg})+\mathrm{CCl}_{4}$.

Trop J Pharm Res, January 2021; 20(1): 116 
Protective effect of extract and fractions on human HepG2 cell lines

The results revealed that $\mathrm{CCl}_{4}$ toxicity decreased cell viability to $39.23 \%$, when compared to 99.9 $\%$ viability in normal control, indicating that $\mathrm{CCl}_{4}$ was very toxic to the cells. However, the methanol extract and its fractions restored the viability of HepG2 cells in a dose-dependent fashion, as shown in Figure 3. At the highest dose of $100 \mu \mathrm{g} / \mathrm{mL}$, the hepatoprotective effects of the ethyl acetate fraction and methanol extract ( 84.5 and $74.2 \%$, respectively) were better than that of the ethyl acetate fraction $(74.2 \%)$. These results are presented in Figure 2.

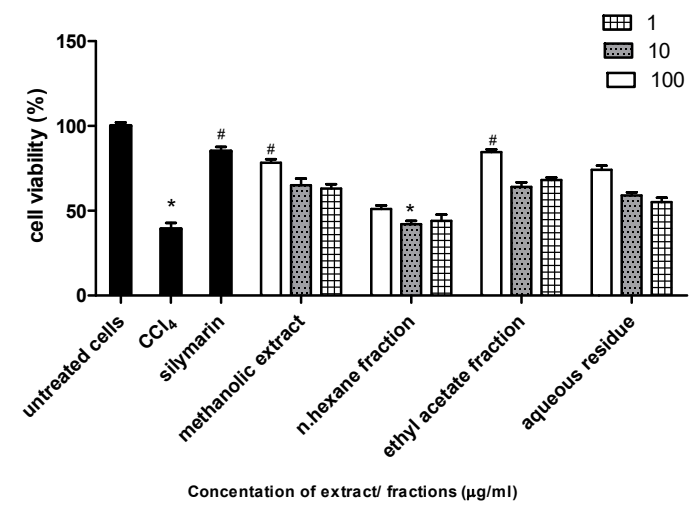

Figure 3: Effect of methanol extract of $F$. carica and its fractions on viability of $\mathrm{CCl}_{4}$-treated $\mathrm{HepG} 2$ cells

\section{DISCUSSION}

The metabolism and detoxification of drugs or xenobiotics in the liver generate highly toxic free radicals as by-products. These free radicals bind to macromolecules and cause oxidative damage to hepatocytes, leading to hepatic injury. Hepatoprotective compounds obtained from plant sources are of great interest to researchers because they have no side effects, unlike synthetic drugs. The protective effect of plants is due to the presence of polyphenols and flavonoid compounds which have antioxidant properties due to their free radical-scavenging capacities [13].

Carbon tetrachloride is used to induce hepatotoxicity in experimental animals. It is a reliable method for screening the hepatoprotective effects of drugs [14]. The drug $\mathrm{CCl}_{4}$ is a biologically inactive and stable molecule. However, it is metabolized by cytochrome p450 system to yield a toxic metabolite. Initially, $\mathrm{CCl}_{4}$ is converted to trichloromethyl free radical, and then in the presence of oxygen, trichloromethyl free radical is converted to trichloromethyl peroxide. These free radicals cause oxidative stress, destruction of plasma membrane and damage to liver tissues [15].

The magnitude of hepatic damage and protection are determined by estimating the serum levels of liver biomarkers such as ALT, AST, bilirubin, ALP and protein [16]. Liver biomarkers are present in the mitochondria of hepatocytes. However, $\mathrm{CCl}_{4}$ damages the hepatocyte membrane, leading to loss of structural integrity and leakage of liver enzymes from the mitochondrion into the blood circulation. Significant increases in the levels of liver biomarkers i.e. ALT, AST, ALP and total bilirubin were observed in the group of mice treated with $\mathrm{CCl}_{4}$. However, these increases were reversed by treatment with plant extract and fractions at doses 200 and $400 \mathrm{mg} / \mathrm{kg}$. Higher significant hepatoprotective effects were produced by treatment with extract and fractions at the higher dose of $400 \mathrm{mg} / \mathrm{kg}$ body weight, indicating that the hepatoprotective effect of Ficus carica was dose-dependent. The observed hepatoprotective effects of Ficus carica extract and fractions are most likely due to the presence of bioactive compounds such as phenolics and flavonoids which have been reported to be present in the plant [17]. Thus, it can be reasonably stated that the $\mathrm{CCl}_{4}$-induced hepatic damage was reversed by phenolics and flavonoids present in the extract and its fractions. The extract fractions also increased serum protein levels which were decreased when animals were administered $\mathrm{CCl}_{4}$.

Carbon tetrachloride $\left(\mathrm{CCl}_{4}\right)$ intoxication results in the formation of highly reactive free radicals. The biological system protects itself from free radicals with the help of endogenous antioxidant enzymes such as reductases, CAT, SOD and GPx. Moreover, the body can be protected via intake of exogenous and natural antioxidant compounds from plants. In this study, the effects of the extract and its fractions on antioxidant defenses in $\mathrm{CCl}_{4}$-toxified mice were determined by assaying the activities of CAT, SOD and GPX.

Hydrogen peroxide is converted into water and molecular oxygen by the endogenous antioxidant enzyme CAT [18]. In this study, administration of Ficus carica extract and fractions enhanced the activity of CAT, resulting in mitigation of $\mathrm{CCl}_{4}$ toxicity in hepatocytes. Superoxide dismutase (SOD) converts the highly reactive superoxide anion $\mathrm{O}_{2}^{-}$to molecular oxygen and hydrogen peroxide. The results obtained in the present study revealed that $\mathrm{CCl}_{4}$ administration suppressed the activity of SOD. This is 
consistent with previous reports. However, treatment with Ficus carica extract and fractions enhanced the activities of the antioxidant enzymes. The endogenous antioxidant enzyme GPx neutralizes free radicals, thereby overcoming the oxidative stress imposed by ROS. In this study, administration of Ficus carica reversed the $\mathrm{CCl}_{4}$-induced decreases in $\mathrm{GPx}$ activity. Histopathology aids in the assessment of the liver damage and hepatoprotective effects of drugs. Several studies have reported structural changes in the liver morphology caused by $\mathrm{CCl}_{4}$ [19].

In vitro systems based on cultured immortalized hepatoma cell lines are widely used to study the effects of toxic substances on hepatocytes [10]. The HepG2 cell lines are extensively used, when compared to primary culture of hepatocytes from animals and man, because it is easy to subject them to cryopreservation and culture. Moreover, the biochemical and morphological characteristics of normal hepatocytes are retained in HepG2 cell lines [21].

The hepatoprotective effects of several plant products against $\mathrm{CCl}_{4}$-induced lesions have been established in studies using HepG2 cell lines. In the present study, MTT assay was applied to determine the hepatoprotective effects of methanol leaf extract of Ficus carica and its fractions on HepG2 cell line. The tetrazolium dye (MTT) is often used to determine the viability and metabolic characteristics of cells based on the conversion of the yellow tetrazolium bromide salt to red fromazan crystals by mitochondrial succinate dehydrogenase.

\section{CONCLUSION}

The results of the present study indicate that the leaves of Ficus carica exert strong protective potential against oxidative stress induced by $\mathrm{CCl}_{4}$. The methanol leaf extract of Ficus carica and its fractions reverses $\mathrm{CCl}_{4}$-induced liver damage, thereby preventing leakage of liver enzymes into blood circulation, and maintaining hepatocyte structural integrity. The extract also restored the activities of liver antioxidant enzymes. The results also reveal that the ethyl acetate fraction produced very high hepatoprotective effect which might be due to the presence of high levels of free radicalscavenging phenolic and flavonoid compounds. Thus, Ficus carica leaves may serve as an alternative to the natural hepatoprotective drug, silymarin.

\section{DECLARATIONS}

\section{Acknowledgement}

The authors would like to thank the Department of Biochemistry, PMAS Arid Agriculture University, Rawalpindi, and National Veterinary Laboratories, Islamabad for providing facilities for this research. No funding was provided.

\section{Conflict of interest}

No conflict of interest is associated with this work

\section{Contribution of authors}

We declare that this work was done by the authors named in this article, and all liabilities pertaining to claims relating to the content of this article will be borne by the authors. SH and HG carried out the study; $R Q$ participated in plant collection and identification, while MG and $\mathrm{SH}$ designed the experiments. $\mathrm{SH}$ wrote the manuscript. SMSN and MG supervised the work. All authors read and approved the final manuscript.

\section{Open Access}

This is an Open Access article that uses a funding model which does not charge readers or their institutions for access and distributed under the terms of the Creative Commons Attribution License (http://creativecommons.org/licenses/by/ 4.0) and the Budapest Open Access Initiative (http://www.budapestopenaccessinitiative.org/rea d), which permit unrestricted use, distribution, and reproduction in any medium, provided the original work is properly credited.

\section{REFERENCES}

1. Raskovic A, Gigov S, Capo I, Kusturica PM, Milijasevic B, Kojic-Damjanov S, Martic N. Antioxidant and protective actions of apigenin in a paracetamol induced hepatotoxicity rat model. Europ J Drug Metabol Pharmacokinetic 2017; 42: 849-856.

2. Ellah MRA. Hepatic oxidative stress: role of liver biopsy. Croatia: INTECH; 2011.p. 76-88.

3. Shyu MH, Kao TC, Yen GC, Hsian T. Mesona Procumbens Heml prevents rat liver fibrosis induced by CCl4 via inhibition of hepatic stellate cell activation. Food Chem Toxicol 2008; 46: 3707-3713.

4. Gautam K, Kumar P. Extraction and pharmacological evaluation of some extracts of Vitex negundo Linn. Int $J$ Pharm Sci 2012; 4: 132-137.

5. Solomon A, Golubowicz S, Yablowicz Z, Grossman S, Bergma M, Gottlieb HE, Altman A, Kerem Z, Flaishman

Trop J Pharm Res, January 2021; 20(1): 118 
MA. Antioxidant activities and anthocyanin content of fresh fruits of common fig (Ficus carica L.). J Agric Food Chem 2006; 54: 7717-7723.

6. Qureshi MN, Bhanudansh SK, Nadeem AL, Majid AH. Invitro antioxidant and in-vivo hepatoprotective activity of Leucas ciliata leaves. Rec Nat Prod 2010; 4(2): 124130.

7. Lowry OH, Rosebrough NJ, Farr AL, Randall RJ. J Biol Chem1951; 193(1): 265-275.

8. Gonzalez-Flecha B, Cutrin JC, Boveris A. Time course and mechanism of oxidative stress and tissue damage in rat liver subjected to in vivo ischemia-reperfusion. $J$ Clin Invest 1993; 91(2): 456-464.

9. Chance B, Maehly AC. Assay of catalase and peroxidase. Methods Biochem Anal 1955; 2: 764-765.

10. Kakkar $P$, Das B, Viswanathan PN. A modified spectrophotometric assay of superoxide dismutase. Indian J Biochem Biophys 1984; 21(2): 130-132.

11. Lawrence RA, Burk RF. Glutathione peroxidase activity in selenium-deficient rat liver. Biochem Biophys Res Commun 1976; 171: 952-958.

12. Thabrew MI, Hughes RD, McFarlane IG. Screening of hepatoprotective plant components using a HepG2 cell cytotoxicity assay. J Pharm Pharmacol 1997; 49: 11321135.

13. Tarner G, Aydin S, Bacanh M, Sarigol Z, Sahin T, Basaran AA, Basaran N. Modulating effect of Pycogenol on oxidative stress and DNA damage induced by Sepsis in rats. Phytother Res 2014; 28: 1692-1700.

14. Abouzied MM, Eltahir HM, Aziz MA, Ahmed NS, ElGhany AA, El-Aziz EA, El-Aziz HO. Curcumin ameliorate DENA-induced HCC via modulating TGFbeta, $A K T$, and caspase-3 expression in experimental rat model. Tumour Biol2015; 36(3): 1763-1771.
15. Khan RA, Khan MR, Sahreen S. CCl -induced $^{-}$ hepatotoxicity: protective effect of rutin on p53, CYP2E1 and the antioxidative status in rat. BMC Complement Altern Med 2012; 12(1): 178.

16. Rajesh A, Vijay K, Pravesh KS. Hepatoprotective models and screening methods: a review. J Discov Ther 2014; 2: $49-56$.

17. Singab AN, Nahla AA, Eman NA, Mostafa MN. Antioxidant and hepatoprotective activities of Egyptian moraceous plants against carbon tetrachloride-induced oxidative stress and liver damage in rats. Pharm Biol 2010; 48(11): 1255-1264.

18. Hsiao G, Lin YH, Lin CH, Chou DS, Lin WC, Sheu JR. The protective effects of PMC against chronic carbon tetrachloride-induced hepatotoxicity in vivo. Biol Pharm Bulletin 2001; 24(11): 1271-1276.

19. Coballase-Urrutia E, Pedraza-Chaverri J, CárdenasRodríguez N, Huerta- Gertrudis B, García-Cruz ME, Ramírez-Morales A, Sanchez-Gonzalez DJ, RiveraEspinosa L, Sampier AL. Hepatoprotective effect of acetonic and methanolic extracts of Heter- otheca inuloides against CCl4-induced toxicity in rats. Exp Toxicol Pathol 2011; 63(4): 363-370

20. Donato MT, Goethals F, Gomez MJ, Deboyser D, Coster DI, Roberfroid M, Castel JV. Toxicity of the antitumoural drug datelliptium in hepatic cells: use of models in vitro for the prediction of toxicity in vivo. Toxicol In vitro 1992; 6: 295-302.

21. Bouma ME, Rogierm E, Verthier N, Barre LC, Feldmann G. Further cellular investigation of the human hepatoblastoma- derived cell line: HepG2 morphology and immune cytochemical studies of hepatic secreted proteins. In Vitro Cell Dev Biol Plant 1989; 25: 267-275. 